\title{
PRODUÇÃO DE MUDAS DE PETÚNIA COMUM EM TUBETES BIODEGRADÁVEIS EM SUBSTITUIÇÃO AOS SACOS PLÁSTICOS
}

\author{
M. V. Ferraz ${ }^{1 *}$, M. P. Cereda ${ }^{2}$, R. A. Iatauro $^{3}$ \\ ${ }^{1}$ UNESP - Univ Estadual Paulista, Câmpus de Registro, SP, Brasil \\ ${ }^{2}$ UCDB - Univ Católica Dom Bosco - CeTeAgro, Campo Grande, MS, Brasil \\ ${ }^{3}$ UNESP - Univ Estadual Paulista, CERAT, Câmpus de Botucatu, SP, Brasil
}

\begin{abstract}
RESUMO
Objetivou-se com este trabalho comparar o desenvolvimento da petúnia nos tubetes biodegradáveis com as mudas nos saquinhos plásticos durante a fase de produção. Foram avaliados a distribuição da massa seca nas três partes da planta (folhas, caule e sistema radicular). Também foi analisado a constituição do tubete e sua perda de massa ao longo do tempo. O delineamento experimental utilizado foi de blocos intereiramente casualizados. A análise utilizou 8 blocos com 16 parcelas em cada bloco, para saquinhos plásticos e tubetes biodegradáveis. No total 128 mudas foram utilizadas para cada embalagem totalizando 256 mudas no experimento. As médias foram submetidas à Análise de Variância, com e sem transformação nos dados e com comparações múltiplas entre as médias pelo Teste de Tukey ao nível de $5 \%$ de significância. A análise dos dados demonstrou que as mudas produzidas nos tubetes biodegradáveis apresentaram desenvolvimento significativamente menor.
\end{abstract}

Palavras-chave: floricultura, deficiência hídrica, biodegradável

\section{SEEDLINGS OF PETUNIA X HYBRIDA IN BIODEGRADABLE TUBES TO REPLACE THE PLASTIC BAGS}

\begin{abstract}
The objective of this study was to compare the development of petunia in biodegradable tubes with seedlings in plastic bags during the production phase. Distribution of dry matter in the three plant parts (leaves stem and root system) were evaluated. Also examined was the constitution of the cartridge and its loss of mass over time. The design was a randomized complete block. The analysis used 8 blocks with 16 plots in each block, plastic bags and biodegradable tubes. In total 128 plants were used for each package totaling 256 seedlings in this experiment. The data were submitted, with and without transformation and multiple comparisons between means by Tukey test at 5\% level of significance. Data analysis showed that seedlings grown in biodegradable tubes had significantly less development.
\end{abstract}

Keywords: flowers, water deficiency, biodegradable

ferraz@registro.unesp.br 


\section{INTRODUÇÃO}

A floricultura no Brasil é típica de pequenos produtores que para sobreviverem precisam conhecer e aplicar técnicas alternativas na produção. A floricultura apresentou um crescimento de 10 a $15 \%$ nos últimos 10 anos, contra um aumento de PIB de 2 a $5 \%$, uma vez que ocorreu o aumento do número de produtores, área de produção, número de variedades e principalmente o consumo (Ibraflor 2014).

Entre os cultivos ornamentais a petúnia foi escolhida por ser muito utilizada na reforma de canteiros floridos nas grandes cidades e por ser ter um grande valor ornamental. Segundo Ferraz \& Cereda (2010) a petúnia é propagada em sementeiras e após 4 a 5 semanas é repicada para saquinhos plásticos, contendo solos com alto teor de argila. Estas mudas, por sua vez, são acondicionadas em pequenas caixas de

\section{MATERIAL E MÉTODOS}

O experimento foi conduzido no Departamento de Recursos Naturais/Ciências Florestais na Fazenda Experimental Lageado da Faculdade de Ciências Agronômicas da UNESP de Botucatu-SP, localizado aos $22^{\circ}$ $51^{`} 14.71^{\prime \prime}$ de latitude Sul, $46^{\circ} 26^{\prime} 00^{\prime \prime} \mathrm{de}$ longitude oeste e altitude média de 786 metros. A temperatura e umidade relativa foi registrada pela estação metereológica da UNESP de Botucatu para o ambiente externo a estufa. Já para o ambiente interno utilizou-se de um termo higrômetro com medidas diárias de temperatura e umidade relativa. Segundo os dados da estação metereológica da UNESP de Botucatu, SP, os meses de agosto e setembro apresentam em ambiente externo temperatura mínima de $13,18^{\circ} \mathrm{C}$ e $17,00^{\circ} \mathrm{C}$; temperatura máxima de $25,01^{\circ} \mathrm{C}$ e $29,86^{\circ} \mathrm{C}$ temperatura média de $17,6^{\circ} \mathrm{C}$ e $21,84^{\circ} \mathrm{C}$ e umidade relativa de $45,38 \%$ e 46,53 respectivamente.

A estufa utilizada apresentava fechamento lateral com tela de sombreamento de $50 \%$ tendo na parte madeira com 15 unidades, que são vendidas quando atingem um tamanho ideal para a comercialização o que acontece com cerca de nove semanas após o transplante. Para o plantio definitivo as mudas devem ser retiradas dos saquinhos plásticos e plantadas em solo preparado, o que demanda tempo, além de aumentar as perdas.

Apesar de muito valorizados por serem mais condizentes com as propostas de conservação do meio ambiente e também por não precisarem ser retirados para o plantio das mudas, poucas informações são disponíveis sobre o uso das embalagens alternativas e biodegradáveis na produção de mudas.

Com isso, a pesquisa foi realizada com o objetivo de verificar o comportamento das plantas em embalagens biodegradáveis, comparando a produção das mesmas em sacos plásticos.

superior um agrofilme de polietileno de 150 micra que permitiu a total passagem da luz. A estufa media $20,00 \mathrm{~m}$ de extensão, $5,00 \mathrm{~m}$ de largura e apresentava um pédireito de 2,80 m. Dotada de sistema de irrigação com distância entre os microaspersores de 3,00 m.

Foram escolhidos os meses de agosto e setembro para a realização deste experimento por respeitar o ciclo da planta que se propaga melhor no final do inverno e início da primavera. Para formar as mudas foram utilizados saquinhos plásticos de polietileno na cor preta (tradicionais) e tubetes biodegradáveis. Os saquinhos tinham $10,00 \mathrm{~cm}$ de comprimento por 5,00 cm de diâmetro, correspondendo a volume de 196,26 $\mathrm{cm}^{3}$ com uma área da boca do saquinho de $19,62 \mathrm{~cm}^{2}$. Os tubetes foram obtidos da empresa Natu-Lyne $\mathrm{L}^{\text {tda }}$ de Botucatu, SP. Estes eram biodegradáveis, com formato cilíndrico-cônicos, elaborados de material fibroso vegetal constituído a base de fécula de mandioca e raspa de madeira de MDF. Não possuem 
estrias internas ou furo para escoamento da água como ocorre com os tubetes de plástico, em razão das paredes serem porosas. Com dimensões de $6,00 \mathrm{~cm}$ de comprimento por $2,50 \mathrm{~cm}$ de diâmetro na abertura superior, correspondiam a volume de $23,00 \mathrm{~cm}^{3}$, com uma área da boca do tubete de 19,62 $\mathrm{cm}^{2}$ (Figura 1).

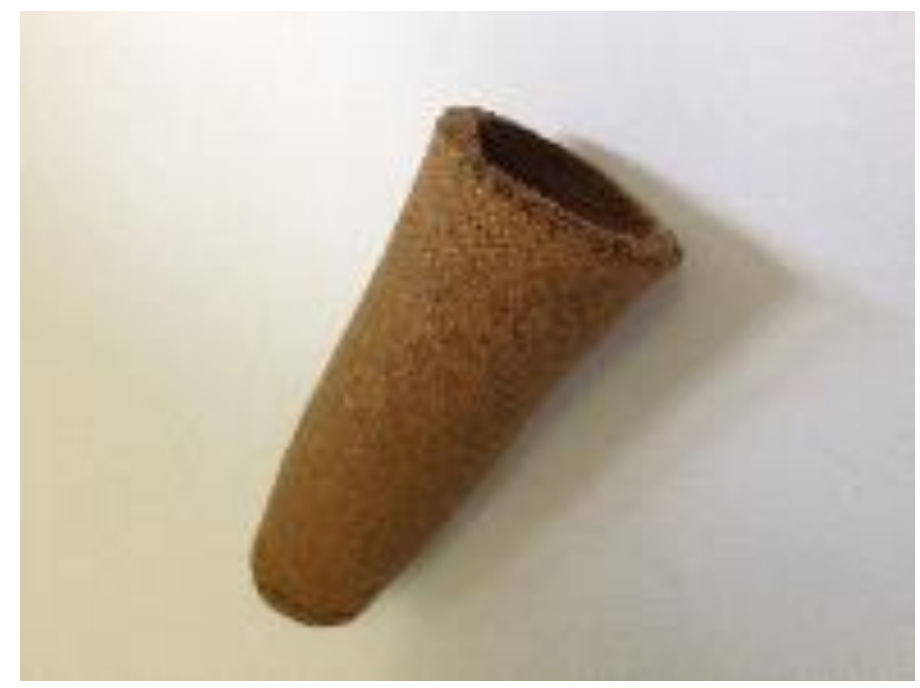

Figura 1 - Tubete biodegradável

Como suporte para os saquinhos plásticos foram utilizadas 8 bandejas de polietileno com dimensões de 30 x $40 \mathrm{~cm}$, proporcionando capacidade máxima para 48 recipientes. Os tubetes biodegradáveis usaram como suporte 4 bandejas de polietileno do tipo utilizado para tubetes plásticos em viveiros, com dimensões de $60 \times 40 \mathrm{~cm}$ e cada uma com capacidade para 176 recipientes. Ambos os suportes foram mantidos em bancada a $50 \mathrm{~cm}$ do solo.

O substrato utilizado foi o PLANTMAX recomendado pelos floricultores. O produto comercial é constituído basicamente por casca de Pinus e vermiculita, com boa porcentagem de macro e micronutrientes. Os tubetes biodegradáveis e os saquinhos plásticos foram preenchidos manualmente com $\mathrm{o}$ substrato até que os recipientes se encontrassem totalmente preenchidos. $\mathrm{O}$ processo era finalizado com irrigação através de regadores manuais até que o substrato ficasse umedecido e na sequiência era feito o plantio das mudas.

Utilizou-se no experimento o sistema de irrigação por aspersão com micro aspersores distanciados de três metros entre si. A água utilizada para a irrigação foi a fornecida pela SABESP. Foram realizadas quatro irrigações por dia, sendo duas no turno da manhã e duas no período vespertino, cada qual de aproximadamente 15 minutos permitindo o total umedecimento do substrato.

Para 0 experimento mudas saudáveis de petúnia-comum (Petunia $x$ hybrida)foram adquiridas da Empresa Nikita, localizada em Holambra, SP. As plantas tinham dois pares de folhas e aproximadamente três centímetros de altura quando foram transplantadas manualmente nos recipientes. Após o plantio todas as mudas foram irrigadas com regadores manuais até $\mathrm{O}$ umedecimento do substrato. A água utilizada para a irrigação do experimento foi captada da empresa SABESP, sendo considerada em perfeitas condições para a irrigação da cultura.

Nos tubetes biodegradáveis e no substrato foram determinados relação $\mathrm{C} / \mathrm{N}$, $\mathrm{pH}$ e condutividade elétrica $(\mathrm{mS} / \mathrm{cm})$. A saturação de água foi feita em um único tubete biodegradável representando todo o lote, previamente pesado e a seguir mergulhado em água por dez minutos até completo encharcamento e novamente pesado. Para estabelecer a quantidade de 
água absorvida e evaporada pelos tubetes biodegradáveis, foi estabelecida a perda de massa deste tubete durante dez horas, após a saturação em água.

A análise de crescimento das plantas de petúnia foi feita pela metodologia proposta por Benincasa (2003), usando plantas previamente sorteadas, que foram cortadas e lavadas. As mensurações foram realizadas semanalmente, sempre no mesmo período do dia, de acordo com a seguinte sequiência: separação dos órgãos da muda (folhas, caule e raiz), com posterior secagem do material em estufa com renovação e circulação de ar MA 037 da marca Marconi a uma temperatura de $60^{\circ} \mathrm{C}$ até massa constante. As características morfológicas avaliadas foram: massa seca das folhas (MSF), massa seca do caule (MSC) e massa seca do sistema radicular (MSR). A Distribuição de Massa Seca (DMS) foi expressa em porcentagem e a

\section{RESULTADOS E DISCUSSÃO}

Conforme dados da estação meteorológica da UNESP de Botucatu, SP, nos meses em que o experimento foi realizado o ambiente externo à estufa apresentou temperatura mínima de $13,18^{\circ} \mathrm{C}$, máxima de $25,01^{\circ} \mathrm{C}$ e umidade relativa de $45,38 \%$. Já ao ambiente interno da estufa registado pelo termo higrômetro apresentou temperatura mínima de $17,00^{\circ} \mathrm{C}$, máxima de $29,86^{\circ} \mathrm{C}$ e umidade relativa de $46,53 \%$ respectivamente.

Tanto a temperatura como a umidade relativa foram considerados adequados para o bom desenvolvimento da petúnia, uma vez que as plantas permaneceram na faixa ótima de temperatura pois não sofreram alterações no crescimento, florescimento e cor das pétalas. Kämpf (2005) cita que as plantas necessitam de temperaturas moderadamente baixas $\left(17,00^{\circ} \mathrm{C}\right.$ durante $\mathrm{o}$ dia, $12,00^{\circ} \mathrm{C}$ à noite $)$ para que ocorra a síntese de antocianinas, distribuição da massa seca nas três partes da planta (folhas, caule e sistema radicular). As pesagens foram feitas em balança digital analítica Marca ADN, modelo HR-200 com pesagens até a quarta casa decimal.

O delineamento utilizado foi de blocos inteiramente casualizados. A análise utilizou 8 blocos, cada bloco era constituído de 16 parcelas . As parcelas eram constituídas de saquinhos plásticos e tubetes biodegradáveis com suas respectivas mudas, somando 128 mudas para cada tratamento, totalizando 256 mudas no experimento. Duas plantas em cada bloco eram sorteadas nas parcelas para serem destruídas como forma de se obter as medidas. As médias foram submetidas à Análise de Variância, com e sem transformação nos dados e com comparações múltiplas entre as médias pelo Teste de Tukey ao nível de $5 \%$ de significância.

tendo algumas variedades um comportamento de exceção, tornando-se mais coloridas em temperatura em torno de $30,00^{\circ} \mathrm{C}$. Segundo Corr (1998) algumas variedades de petúnia podem tolerar até 35 a $38,00^{\circ} \mathrm{C}$ de temperatura máxima. Syngenta Seeds (2005), cita que para as plantas de petúnia retomem seu crescimento após o transplante, a temperatura deve ser mantida no intervalo de 18 a $20,00^{\circ} \mathrm{C}$.

Segundo Benincasa (1986) a distribuição da massa seca permite inferir a translocação orgânica, o que facilita bastante a compreensão do comportamento do vegetal em termos de produtividade.

Em relação ao desenvolvimento das plantas de petúnia observou-se que para ambos os recipientes foi necessário um período de adaptação das mudas transplantadas ao novo substrato. 


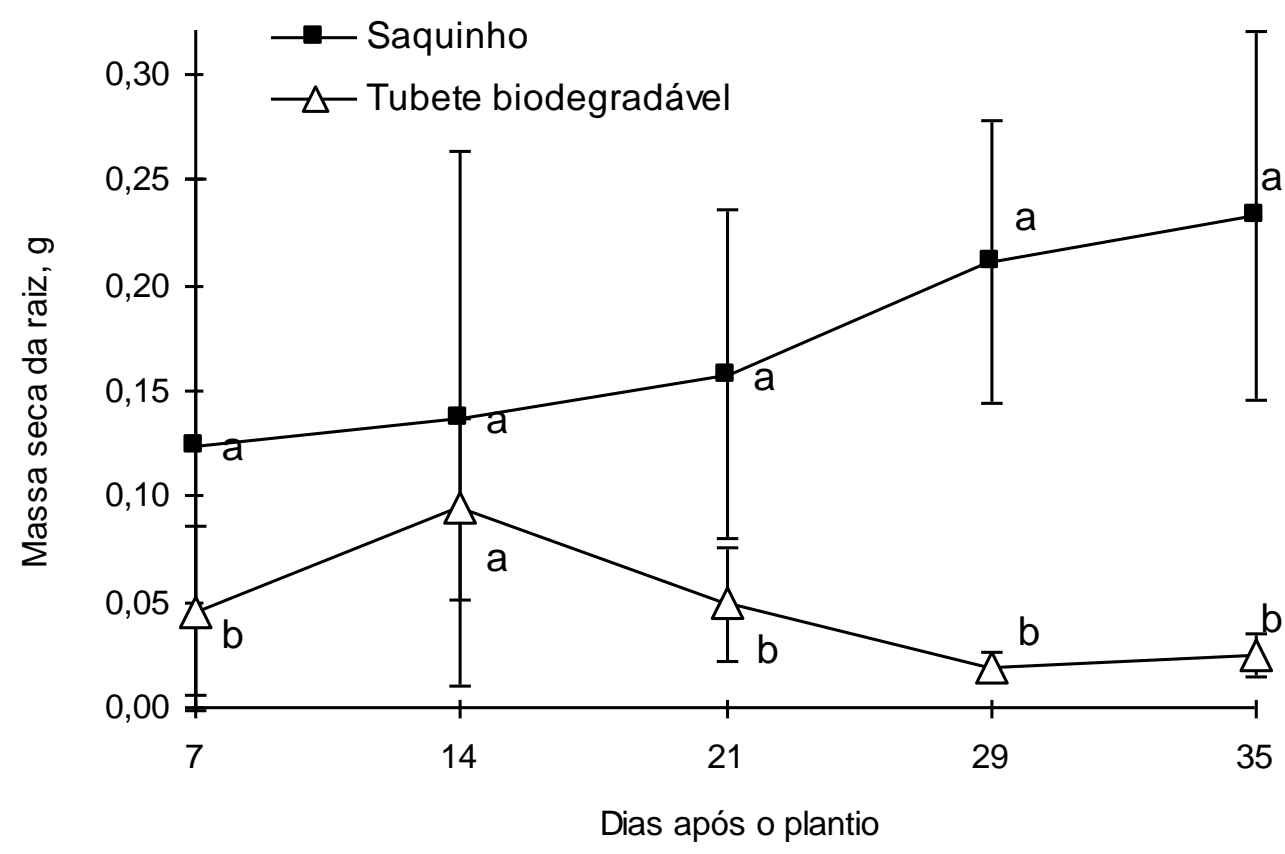

Figura 2 - Massa seca da raiz (MSR) em gramas (g) das plantas dos saquinhos plásticos e tubetes biodegradáveis

A Figura 2 demonstra que as mudas transplantadas para que os sacos plásticos produziram massa seca radicular estatisticamente superior àquelas das mudas dos tubetes, exceto na segunda semana quando não foi observada diferença. Este resultado leva a crer que após o transplante as plantas dos tubetes sofreram mais. A redução da massa seca das raízes das mudas dos tubetes biodegradáveis que se observa a partir da terceira semana do transplante pode refletir a translocação de nutrientes desse órgão para outras partes da planta

A empresa Latu-Lyne informou que o menor tamanho dos tubetes biodegradáveis foi determinado em razão do fato de que, contrariamente ao que ocorre com os tubetes plásticos e saquinhos tradicionais, as raízes das plantas atravessam suas paredes porosas, não explorando todo o volume de substrato. Com tubetes mais curtos não ocorre esse desperdício.

Essa característica também pode explicar a menor quantidade de massa seca das raízes. Segundo Bôhm (1979) citado por Gomes (2003) os volumes dos recipientes influenciam a disponibilidade de nutrientes e água e, o maior volume promove a melhor arquitetura do sistema radicular. 


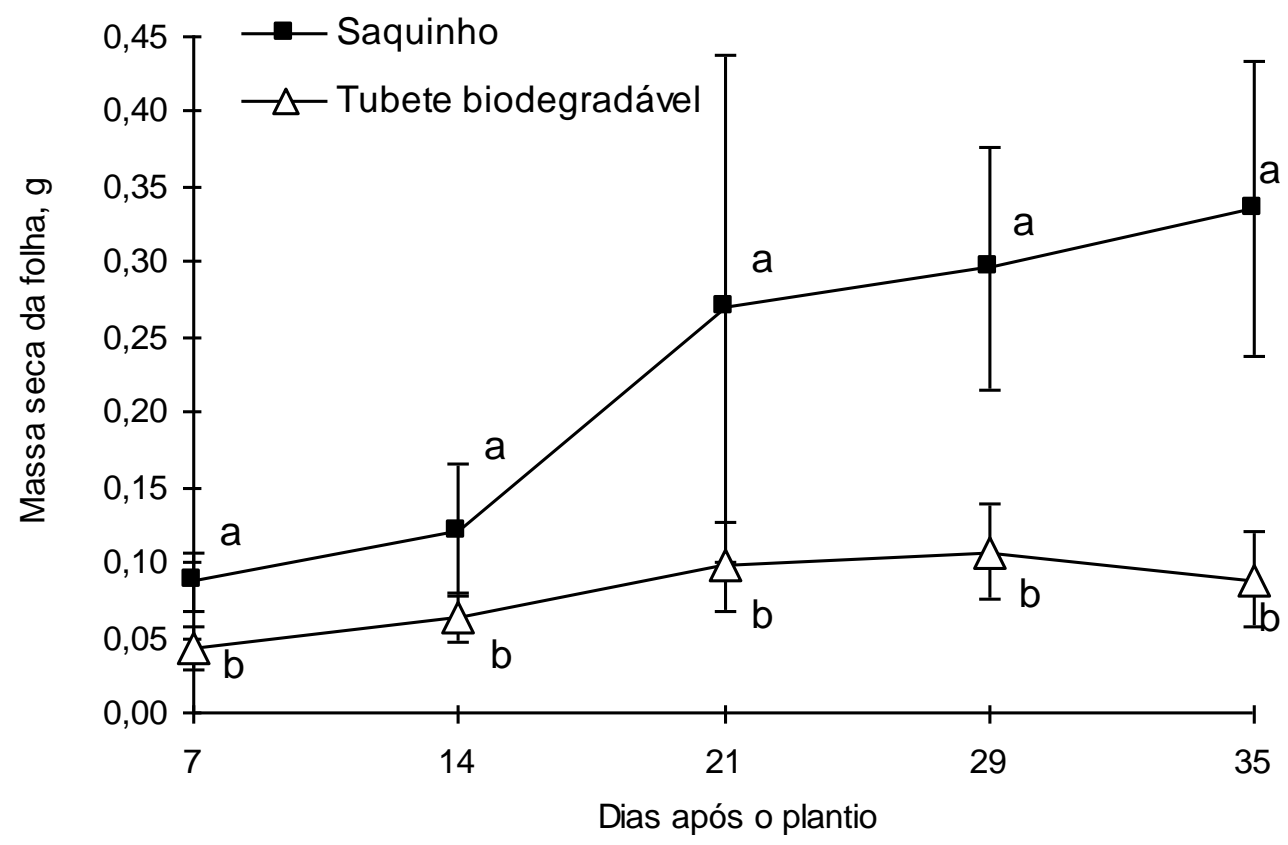

Figura 3 - Massa seca da folha (MSF) em gramas (g) das plantas dos saquinhos plásticos e tubetes biodegradáveis

Com relação à massa seca da folha (Figura 3), todas as avaliações mostram que a massa seca dos caules das plantas transplantadas em saquinhos plásticos
(Figura 4) foram significativamente maiores, com exceção daquelas da primeira amostragem.

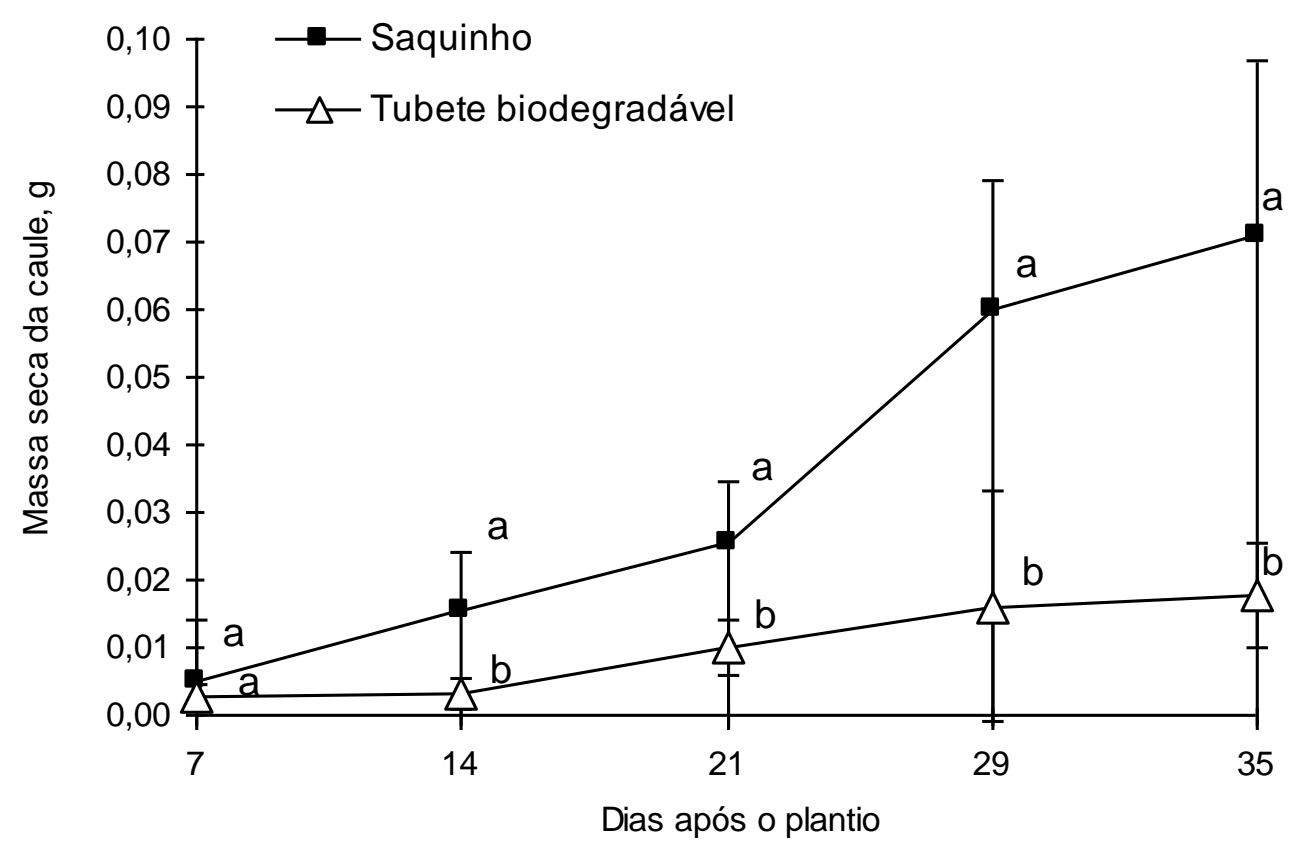

Figura 4 - Massa seca do caule (MSC) em gramas (g) das plantas dos saquinhos plásticos e tubetes biodegradáveis

Esses resultados também podem ser explicados porque estas plantas com maior superfície de contato com o substrato em razão da maior massa seca de raízes, podem absorver e translocar maior quantidade de assimilados paras as demais partes da planta. 
Os dados de desenvolvimento das plantas mostraram que a quantidade de massa seca foi bem maior nas folhas (59 e $52 \%$ ), seguida das raízes (40 e $34 \%$ ) e por último dos caules $(8$ e $7 \%)$, respectivamente para mudas dos saquinhos e dos tubetes biodegradáveis.

Esse comportamento pode ser encontrado em alguns vegetais nos quais a quantidade de massa seca é maior nas folhas. A explicação segundo Kerbauy (2004), seria de que, uma vez que a planta fixa o carbono e o converte em sacarose, a maior parte do carbono fixado na fotossíntese é utilizada para a formação de carboidratos, principalmente sacarose e amido. Segundo Raven et al. (1992), embora a glicose seja normalmente representada como um produto da fotossíntese nas equações resumidas, na realidade muito pouca glicose livre é gerada pelas folhas fotossintetizantes. Os mesmos autores citam que a maior parte do carbono fixado é convertida, preferencialmente, em sacarose, o principal açúcar de transporte das plantas, ou em amido, o principal carboidrato de reserva das plantas.

A petúnia é uma planta que não possui órgãos de reserva, ao contrário do que ocorre na beterraba e na cenoura, que apresentam raízes tuberosas, com acúmulo de açúcar e amido e, como consequência apresenta maior massa seca nas raízes.

Segundo Iatauro (2004) o sentido de translocação da massa seca é determinado pelos genes da planta, que por sua vez podem ser influenciados pelo ambiente.

No experimento esperava-se pouca influência destes fatores uma vez que as mudas utilizadas no experimento foram da mesma espécie, tanto com tubetes biodegradáveis como com saquinhos plásticos, além do fato do experimento ter sido planejado de forma a proporcionar as mesmas condições ambientais paras as mudas dos dois tipos de recipientes utilizados. Por essas razões, um dos fatores que pode explicar o baixo desenvolvimento das raízes das mudas dos tubetes é o volume de substrato, que nos tubetes biodegradáveis foi cerca de 8 vezes menor que $o$ dos saquinhos plásticos. Provavelmente em função deste maior volume as mudas dos saquinhos plásticos dispuseram de maior quantidade de nutrientes e de água para seu desenvolvimento. Como o tempo e volume de água de irrigação foram iguais para os dois tipos de embalagens a explicação encontrada para o aspecto mais ressecado dos tubetes biodegradáveis foi a natureza porosa de suas paredes em razão do uso de material fibroso.

Outro fator que poderia explicar a menor disponibilidade de água para as mudas de tubetes biodegradáveis em relação às de sacos plásticos seria a acidez e salinidade presentes no material orgânico em razão de sua decomposição microbiana, uma vez que no experimento o mesmo substrato foi utilizado nos saquinhos plásticos e nos tubetes biodegradáveis.

Os resultados da relação $\mathrm{C} / \mathrm{N}$, $\mathrm{pH}$ e condutividade elétrica $(\mathrm{mS} / \mathrm{cm})$ dos tubetes biodegradáveis foram de 14/1, 4,51 e 1,72 respectivamente. Já os valores encontrados na análise do substrato foram 32/1 para relação $\mathrm{C} / \mathrm{N}, 4,47$ para $\mathrm{pH}$ e $0,87(\mathrm{mS} / \mathrm{cm})$ de condutividade elétrica. Por apresentar relação $\mathrm{C} / \mathrm{N}$ de $32 / 1$ o tubete teria tendência a se degradar mais rapidamente que o substrato com relação 14/1. As características químicas do saquinho plástico não interferiram no desenvolvimento da petúnia, já que o plástico é inerte.

O tubete pode ser considerado como o conjunto do substrato envolvido por material biodegradável. $\mathrm{O} \mathrm{pH}$ do tubete biodegradável foi próximo daquele do substrato embora fosse inferior ao recomendado como ideal para o desenvolvimento da petúnia.

Como para Corr (1998) a cultura da petúnia se desenvolve bem em substrato com pH em torno de 5,50 a 6,30 e condutividade elétrica em torno de 0,75 $(\mathrm{mS} / \mathrm{cm})$, as condições encontradas no tubetes propriamente não devem ter interferido no desenvolvimento das petúnias. 
Observou-se

crescimento

satisfatório das raízes das mudas plantadas nos saquinhos, comprovado pela coloração normal das folhas das mudas de petúnia, que não apresentaram as manchas foliares características de desenvolvimento em $\mathrm{pH}$ muito baixo. As mudas dos tubetes biodegradáveis também não apresentaram manchas, porém obtiveram um crescimento menor.

A hipótese de que a condutividade elétrica possa ter interferido negativamente no desenvolvimento das plantas dos tubetes foi aventada uma vez que, sendo poroso, a água da irrigação podia evaporar na superfície externa da parede porosa, aumentando a salinidade e prejudicando o desenvolvimento das raízes de petúnia. Entretanto, o maior valor observado no material do tubete em relação ao substrato também não justifica a diferença de crescimento observada entre as plantas dos saquinhos e dos tubetes, uma vez que já na primeira semana do experimento a diferença de peso seco do sistema radicular já era significativamente maior nas mudas dos saquinhos de saquinhos, em relação as de tubetes, fase esta em que as raízes ainda não estavam próximas fisicamente com o material do tubete.

Também foi observado que as raízes atravessam as paredes porosas dos tubetes biodegradáveis e paravam de crescer quando entravam em contato com a luz, caracterizando da poda fisiológica, o que reduziu ainda mais o volume do sistema radicular já menor em razão do menor volume do recipiente.

A hipótese de deficiência hídrica para explicar a falta de desenvolvimento das mudas de tubetes, levou a necessidade de avaliar o mecanismo de absorção e evaporação de água pelo material com o qual os tubetes eram confeccionados.

A Figura 5 apresenta o resultado da avaliação da capacidade de armazenar e perder água, simulada pela imersão em água do tubete sem substrato, com posterior drenagem e secagem.

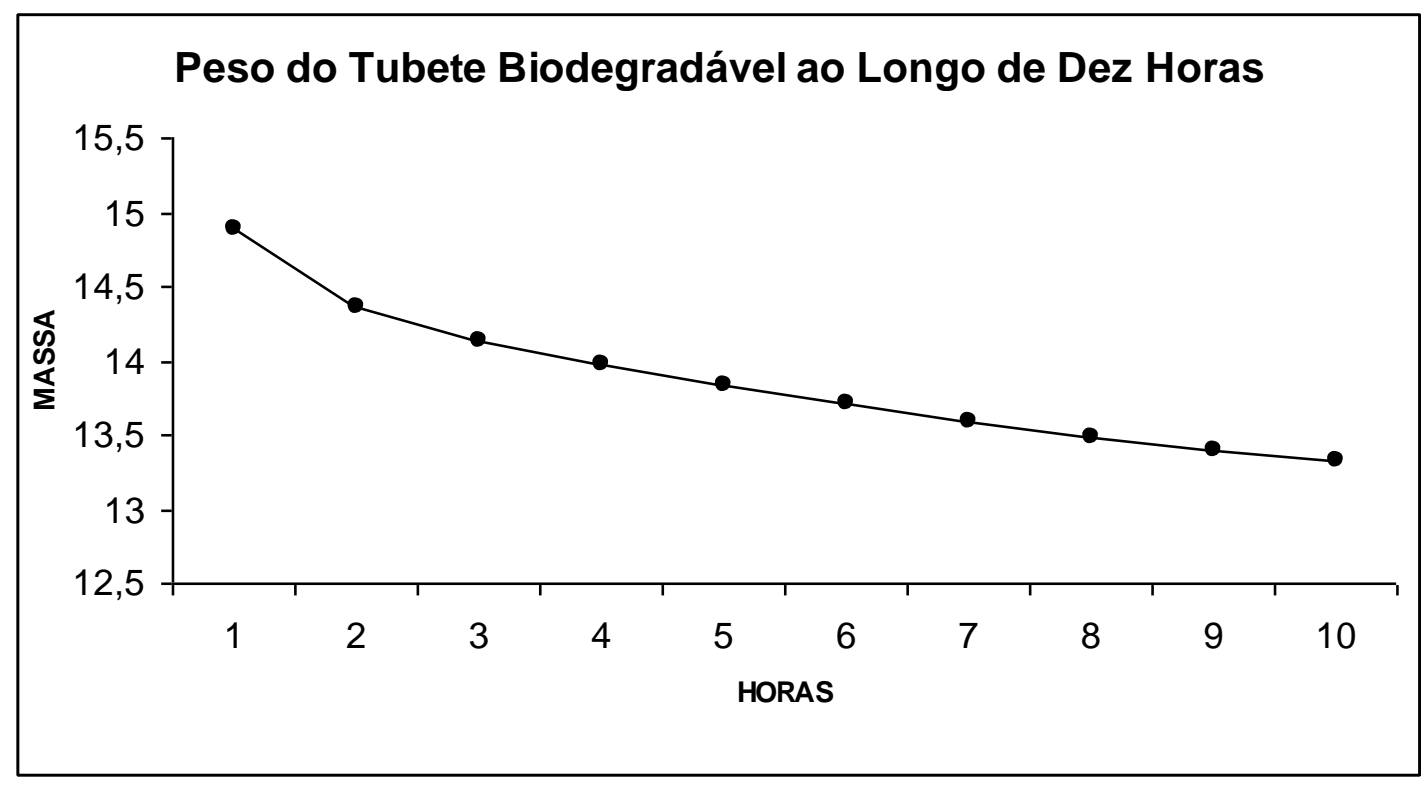

Figura 5 - Perda de massa de água ao longo do tempo de um tubete biodegradável

Para a avaliação o tubete ficou 0 tempo inteiro em condições ambiente. Com peso seco inicial de cerca de 13 gramas, o tubete biodegradável ganhou a cada hora 2,15 gramas, o que representou um acréscimo de 16,87\% em relação a seu peso seco. Entretanto, após 10 horas de drenagem em ambiente natural, o tubete havia perdido 1,57 gramas de água, o que representou uma perda $10,57 \%$ de seu peso encharcado. Esses resultados complementam as poucas informações na literatura relativas as características dos materiais biodegradáveis, mostrando que a 
vantagem de absorver e reter água, pode ser compensada pela maior e mais rápida perda da mesma água, reduzindo a quantidade de água disponível para a planta.

Mesmo que no tubete preenchido com substrato esta perda de água possa ser mais lenta, uma vez o substrato também retém água, pode-se afirmar que nas condições em que o experimento foi conduzido, formou-se um gradiente de perda de água do substrato para a parede externa do tubetes e daí para o ambiente. Com isso o substrato deve ter proporcionado menos água livre, prejudicando o bom desenvolvimento radicular das plantas, em relação as mudas de sacos plásticos, como comprova a Figura 1 onde as raízes das mudas dos tubetes não se desenvolveram a contento.

$$
\text { Iatauro (2004) avaliou o }
$$

desenvolvimento das mudas de aroeira em tubetes biodegradáveis semelhantes aos usados nesta pesquisa. $\mathrm{O}$ autor concluiu que os tubetes funcionam como uma "esponja" absorvendo a água retida no substrato, juntamente com parte dos minerais, que se depositariam nas paredes externas do tubetes com a evaporação. Essa hipótese encontra apoio no relato de Oliveira \& Fiorine (2006) de problemas no crescimento de plantas de mandioca em tubetes biodegradáveis, que foram relacionados à altos teores de sódio detectados nos tubetes.

Além do fenômeno normal de perda de água para o ambiente, esse fenômeno de remoção de água e nutrientes do substrato, poderiam explicar o baixo crescimento radicular apresentado pelas mudas desenvolvidas nos tubetes, quando comparada às mudas dos saquinhos plásticos.

\section{CONCLUSÃO}

A análise dos dados mostrou que o uso dos tubetes pode ser uma realidade desde que se faça algumas alterações principalmente em sua forma, aumentando a sua largura. Novas pesquisas devem ser realizadas levando em consideração uma
Esse mecanismo poderia também ter sido agravado pela distribuição desigual da irrigação, embora o volume e tempo de aspersão tenham sido os mesmos para tubetes e saquinhos plásticos. Ocorre que os tubetes apresentavam menor superfície de captação $\left(4,90 \mathrm{~cm}^{2}\right)$ que os saquinhos plásticos $\left(19,62 \mathrm{~cm}^{2}\right)$ em função do menor diâmetro, o que pode ter reduzido a captação de água nas mesmas condições de irrigação.

Uma opção para reter mais água seria a adição ao substrato de polímeros hidroretentores na forma de pó ou hidratados ao substrato, embora ocasionando custo adicional. Esses polímeros são produtos utilizados em plantios comerciais por sua capacidade de absorver e armazenar água (Moraes, 2001), que é liberada gradualmente.

Considerando que a maior limitação ao uso dos tubetes biodegradáveis seria o déficit hídrico, uma solução menos onerosa a ser considerada para evitar esse fenômeno seria a alteração do manejo da irrigação para compensar a porosidade do material biodegradável. Isso poderia ser feito, parcelando o volume necessário, em maior número de irrigações no dia.

O uso de tubetes biodegradáveis é recente e a literatura é ainda escassa. Os resultados mostraram que as condições de manejo usadas na produção de mudas de petúnias deverá ser adaptada às característica e necessidades deste novo material a fim de melhor utilizar suas vantagens de possibilitar plantio direto, sem replante. $\mathrm{O}$ simples manejo de irrigação, como aumento de número de aspersões para o mesmo volume de água poderá favorecer um melhor desenvolvimento das plantas.

nova dimensão e formato destes tubetes. Hoje a busca por novas embalagens recicláveis e a agricultura orgânica pode ser o alvo de mercado para este produto. Novas pesquisas devem ser feitas com a finalidade de comprovar a utilidade deste 
novo material que é livre de compostos derivados de petróleo e ecologicamente correto. Outra importância é que estes reciclam resíduos em sua confecção que outrora eram despejados no lixo. De forma

\section{REFERÊNCIAS BIBLIOGRÁFICAS}

BENINCASA, M. M. P. Análise de crescimento de plantas: noções básicas.2.ed. Jaboticabal: FUNEP, 2003. $41 \mathrm{p}$.

BENINCASA, M. M. P. Análise de crescimento de plantas: noções básicas.

Jaboticabal: FUNEP, 1986. 42p.

CORR, B. Pan American Seeds. 16. ed. Illinois , USA: Ball red Book, 1998. 649p.

FERRAZ, M.V e CEREDA, M. P. Determinação das características morfológicas de Petúnias-Comuns (Petunia $\mathrm{x}$ hybrida) cultivadas em Tubetes Biodegradáveis. Revista Scientia Agraria Paranaensis. Botucatu-SP. V.09, n.1, p. 94107, 2010.

GOMES, J. M.; Couto L.; , Leite H. G.; Xavier, A. e Garcia, S. L. R. Crescimento de mudas de eucalyptus grandis em KERBAUY, G. B. Fisiologia Vegetal. $1^{\circ}$ ed. Rio de janeiro: Guanabara koogan S.A, 2004. 452p.

MENDONÇA, V., NETO, S. E. A., RAMOS, J. D., PIO, R. e GONTIJO, T. C. A. Diferentes substratos e recipientes na formação de mudas de mamoeiro "SUNRISE SOLO". Revista Brasileira de Fruticultura, Jaboticabal, v. 25, p. 127-130, 2003.

MORAES, O. Efeito do uso de polímero hidroretentor no solo sobre o intervalo de irrigação na cultura da alface(Lactuca sativa L.). 2001. 73 f. Tese (Doutorado em Agronomia) - Escola Superior de Agricultura Luiz de Queiroz, Piracicaba, 2001.

OLIVEIRA, M.A e FIORINE, R. A. Análise De Crescimento Em Mudas De Mandioca (Manihot Esculenta Crantz) Provenientes De Estacas Em Diferentes geral, as mudas dos tubetes biodegradáveis desenvolveram menor quantidade de massa seca nas raízes, folhas e caules que as mudas dos saquinhos plásticos.

diferentes tamanhos de tubetes e fertilização N-P-K. Revista Árvore. Viçosa-MG, v.27, n.2, p.113-127, 2003

IATAURO, A. R. Avaliação energética da substituição de tubetes de plástico por tubetes biodegradáveis na produção de mudas de aroeira- Schinus terebinthifolius Raddi. Botucatu: FCA-UNESP, 2004. 59p. Dissertação (Mestrado em Energia na Agricultura)

IBRAFLOR. Nova Fotografia do Setor de Flores e Plantas Ornamentais e seus principais gargalos. IBRAFLOR. 2014 Disponível em: http://www.ibraflor.com/ns_mer_interno.p $\mathrm{hp} /$ Acesso em 29/05. 2014.

KÄMPF, A. N. Produção comercial de plantas ornamentais. $1^{\circ}$ ed. Guaíba: Agropecuária, 2005. 256p.

Recipientes Para Cultivo. Revista Raízes e Amidos Tropicais. Botucatu, V. 2, p.12-26, outubro, 2006

RAVEN, P.H., EVERT, R. F e SUSAN, E. E. Biologia Vegetal. $1^{\circ}$ ed. Rio de janeiro: Guanabara, 1992. 906.

SYNGENTA SEEDS. Petúnia $\mathrm{x}$ hybrida. Syngenta on Line, São Paulo, não paginado, 2005. Disponível em: <http://www.syngentaseeds.com.br/syngen taseeds.com.br_non_ssl/novosite/petunia.a sp Acesso em: 20/07. 2005. 